\title{
Medievalista
}

Online

$27 \mid 2020$

Número 27

\section{O cruzeiro medieval de Tavira}

Tavira's medieval stone cross

Daniel Santana e Marco Sousa Santos

\section{(2) OpenEdition}

Journals

Edição electrónica

URL: http://journals.openedition.org/medievalista/2820

ISSN: 1646-740X

\section{Editora}

Instituto de Estudos Medievais - FCSH-UNL

\section{Refêrencia eletrónica}

Daniel Santana e Marco Sousa Santos, « O cruzeiro medieval de Tavira », Medievalista [Online], 27 | 2020, posto online no dia 01 janeiro 2020, consultado o 28 dezembro 2019. URL : http:// journals.openedition.org/medievalista/2820

\section{(c) (7) (5)}

Mediavalista está licenciado com uma Licença Creative Commons - Atribuição-NãoComercial 4.0 Internacional. 
Título / Title (Português e Inglês): O cruzeiro medieval de Tavira / Tavira's medieval stone cross

Autor(es) / Author(s): Daniel Santana (a); Marco Sousa Santos (b)

Afiliação institucional / Institutional affiliation (Universidade, Faculdade, Departamento ou Unidade de Investigação / University, Faculty, Department or Research Centre): (a) Museu Municipal de Tavira, Câmara Municipal de Tavira; (b) Centro de Estudos de Arqueologia, Artes e Ciências do Património da Universidade de Coimbra, 3000-395 Coimbra, Portugal

Código postal / Postcode; Cidade / City; País / Country: (a) 8800-394, Tavira, Portugal; (b) 3000-395 Coimbra, Portugal

ORCID: (a) https://orcid.org/0000-0001-8483-3461 ; (b) http://orcid.org/0000-0003-4975763X

Email Institucional / Institutional email:

(a)daniel@cm-tavira.pt; (b) marcosousasantos@hotmail.com

Fonte: Medievalista [Em linha]. Direc. Bernardo Vasconcelos e Sousa. Lisboa: IEM. Disponível em: http://www2.fcsh.unl.pt/iem/medievalista/santana-santos2702 ISSN: 1646-740X

DOI : 10.4000/medievalista.2820

Data recepção do artigo / Received for publication: 28 de Maio de 2018

Data aceitação do artigo / Accepted in revised form: 29 de Abril de 2019 


\section{Resumo}

Durante séculos ignorada ou erroneamente identificada como um capitel ou parte de um antigo pelourinho, tudo indica que a peça de cantaria lavrada, guardada no espólio do Museu Municipal de Tavira (Palácio da Galeria), e até agora apenas identificada com o código MMT2285, é na verdade um elemento de um desaparecido cruzeiro medieval. Provavelmente executada numa oficina da região algarvia no século $\mathrm{XV}$, num dos períodos de maior prosperidade da povoação, esta peça terá originalmente estado colocada num espaço privilegiado do ponto de vista urbanístico, possivelmente numa das entradas da então vila ou, em alternativa, nas proximidades do antigo convento de São Francisco.

Palavras-chave: Escultura medieval, Cruzeiro, Tavira.

\section{Abstract}

For centuries ignored or wrongly identified as a chapiter or part of a pillory, it is possible that the carved stone piece stored in the municipal museum of Tavira (Palácio da Galeria) - so far only identified with the code MMT228 - is actually an element of a vanished medieval stone cross. Probably executed in the Algarve region in the fifteenth century, one of the periods of greatest prosperity of the village, this piece was originally placed in an urban privileged space, possibly in one of the village entries, or perhaps near the ancient convent of Saint Francis.

Keywords: Medieval sculpture, Stone cross, Tavira. 


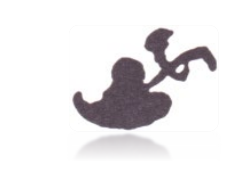

\section{O cruzeiro medieval de Tavira / Tavira's medieval stone cross}

\section{Daniel Santana, Marco Sousa Santos}

O intitulado Jardim de São Francisco, em Tavira, funcionou durante décadas como um depósito improvisado onde se recolheram, a céu aberto e no interior de duas antigas capelas medievais desativadas, capitéis, epígrafes, pedras tumulares, pedras de armas e toda uma panóplia de fragmentos e peças de cantaria oriundas de diferentes construções da cidade. Entre essas peças estava o elemento de cantaria lavrada que constitui o objeto do presente estudo e ao qual, depois de integrado na coleção do Museu Municipal de Tavira (Palácio da Galeria), foi atribuída a referência MMT2285.

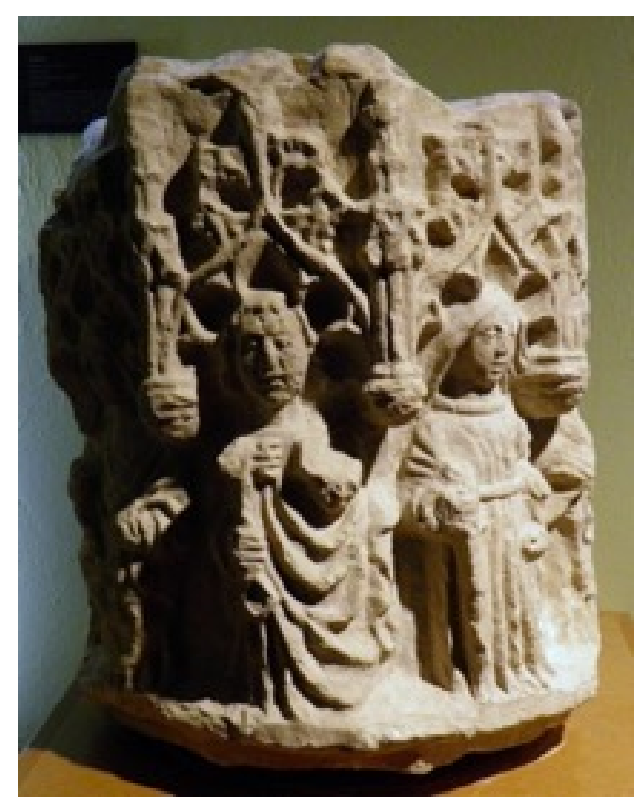

Fig. 1 - Peça medieval de cantaria no Museu Municipal de Tavira e identificada com a referência MMT2285. Fonte: fotografia dos autores, 2014. 


\section{O estado da questão}

No ano de 2013, no âmbito da exposição Memória e Futuro, foi exposta no museu de Tavira (Palácio da Galeria) uma invulgar cantaria lavrada identificada com a referência MMT2285, peça de planta circular, com cerca de 50 centímetros de altura e 40 centímetros de largura, esculpida em todo o perímetro e parcialmente fragmentada. A legenda que acompanhava a peça identificava-a como um provável capitel, de origem desconhecida, que tinha sido recolhido no jardim público anexo à igreja da Ordem Terceira de São Francisco e que admissivelmente seria oriundo de uma das antigas Casas religiosas da cidade.

Sublinhe-se, esta peça já tinha sido anteriormente integrada noutra exposição do mesmo museu, realizada em 2003 e intitulada Tavira: Território e Poder. No catálogo dessa exposição ela é descrita como uma "peça de exterior", circunstância desde logo sugerida pelo elevado grau de erosão que apresenta (provavelmente causada pelos agentes atmosféricos), concluindo-se tratar-se de um possível "capitel de pelourinho". No que respeita à cronologia, tendo por base o recorte dos arcos e a tipologia dos panejamentos das figuras representadas, Carla Varela Fernandes propõe no catálogo da exposição tratarse de uma peça datável de meados do século XV. Em relação à proveniência, a autora apenas adianta que a peça era proveniente do Jardim de São Francisco, em Tavira, onde, em época que não se podia precisar, fora reaproveitada na montagem de um pelourinho, constituindo o remate de um conjunto que integrava ainda uma coluna de fuste liso e um capitel coríntio da época romana (este possivelmente oriundo da povoação ibero-romana de Balsa), colocado em posição invertida, o qual lhe servia de base, desconhecendo-se, não obstante, a sua origem ${ }^{1}$.

De facto, no que respeita à origem desta peça, a única coisa que se pode assegurar é que, antes de ser integrada nas coleções do museu municipal, ela estava, como se disse, colocada no topo de uma antiga coluna de cantaria, em pleno Jardim de São Francisco, configurando um pelourinho improvisado, já que há registos fotográficos da década de 90 do século XX que mostram a peça levantada nesse mesmo local. A esse respeito, talvez valha a pena lembrar que o espaço onde hoje se encontra o jardim (no qual se situavam

\footnotetext{
${ }^{1}$ FERNANDES, Carla Varela - "Fichas de catálogo". in Tavira - território e poder (catálogo de exposição). Tavira: Câmara Municipal de Tavira / Museu Municipal (Palácio da Galeria), 2006, p. 316.
}

Medievalista № 27 | Janeiro - Junho 2020 ( ) IEM - Instituto de Estudos Medievais 4 www2.fcsh.unl.pt/iem/medievalista 
outrora a nave e as dependências claustrais do extinto convento de São Francisco) foi adquirido pela Câmara de Tavira em 1844, com o objetivo de nele se instalar um cemitério público. Só após a desativação desse cemitério, em 1918, o espaço é destinado a viveiro de plantas e, finalmente, a jardim municipal ${ }^{2}$.

Sabe-se que a peça em causa já se encontrava no dito jardim no ano de 1937, data em que, na obra Notícias Históricas de Tavira (1242-1840), Damião Augusto de Brito Vasconcelos refere a existência, nesse espaço ajardinado, daquilo que afirma ser um "antiquíssimo cruzeiro que dantes se erguia fronteiro à primitiva igreja franciscana". Ou seja, o autor vai identificar esta peça como um "cruzeiro", não como um elemento do pelourinho, avançando inclusive que ela teria anteriormente estado colocada em frente à desaparecida igreja do extinto convento dos franciscanos ${ }^{3}$.

De algum modo corroborando a interpretação feita por Damião de Vasconcelos, sem, contudo, a subscrever na íntegra, em 1966, num texto publicado na imprensa local, Armando da Costa Franco identifica a peça de cantaria que se erguia no Jardim de São Francisco como um "pelourinho ou cruzeiro", acrescentando que, segundo a tradição, a mesma seria proveniente do adro de uma antiga capela dedicada a Nossa Senhora do Espinheiro que tinha existido na Atalaia, no limite do núcleo urbano. Mas que, segundo testemunhos orais, também teria estado colocada na então Praça da República, junto ao edifício dos Paços do Concelho ${ }^{4}$.

Tanto quanto foi possível apurar, nenhum outro autor voltou a tratar este tema. Portanto, o que se sabe acerca da peça em questão é que já foi identificada como elemento de um cruzeiro ou de um pelourinho. Unicamente a questão cronológica parece reunir algum consenso, acordando os autores na hipótese de se tratar de uma peça datável de meados do século XV. Em relação à respetiva proveniência, apenas se sabe que terá permanecido no Jardim de São Francisco, onde já se encontrava em 1937, até aos derradeiros anos do século $\mathrm{XX}$, data em que foi recolhida nas reservas do museu. No que diz respeito ao

\footnotetext{
${ }^{2}$ ANICA, Arnaldo Casimiro - Tavira e o seu Termo - Memorando Histórico. Vol. II. Tavira: Câmara Municipal de Tavira, 2001, pp. 161-162.

${ }^{3}$ VASCONCELOS, Damião Augusto de Brito - Notícias históricas de Tavira (1242-1840), 2 edição (com anotações de Arnaldo Casimiro Anica). Tavira: Câmara Municipal de Tavira, 1999, pp. 279-280.

${ }^{4}$ FRANCO, Armando da Costa - "Subsídios para o Museu de Tavira". Jornal do Sotavento (3 de maio de 1996). Tavira: 1996.
} 
original local de implantação, e segundo as notícias recolhidas pelos diversos autores que se debruçaram sobre o tema, as opiniões divergem, admitindo-se que a peça possa ter estado colocada em distintos espaços públicos da cidade, nomeadamente no adro da antiga igreja conventual de São Francisco, no adro da ermida do Espinheiro, na Atalaia, e até na Praça da República. Persistem, portanto, as dúvidas em relação à origem da peça, bem como à sua definitiva identificação do ponto de vista funcional.

\section{Breve descrição formal e proposta de leitura iconográfica}

A erosão provocada pela prolongada exposição da peça aos agentes atmosféricos, bem como o facto de se encontrar parcialmente mutilada, acaba por de algum modo dificultar a leitura e a análise dos seus relevos decorativos. Não obstante, é possível afirmar que este alegado capitel exibe um total de oito figuras antropomórficas trabalhadas em baixo relevo e enquadradas superiormente por uma sequência de arcos conopiais e polilobados idênticos, cujo recorte aponta, como anteriormente dito, para uma cronologia de meados do século $\mathrm{XV}$, sendo de realçar o dinamismo transmitido pelo rendilhado tardogótico das arcarias e pelas roupagens das figuras marcadas por profundas pregas verticais e oblíquas. Refere Carla Varela Fernandes a este respeito:

“a disposição das figuras, bem como o enquadramento arquitetónico, formado por arcarias separadas por torres e pináculos, remetem para uma tradição decorativa bem assente no território nacional, especialmente relacionável com a decoração das arcas tumulares, desde meados do século XIII"5.

Assim, este elemento torna-se particularmente relevante para a história da arte medieval no Algarve por apresentar um programa iconográfico rico, de assinalável impacto visual e sem paralelo na região mais meridional do país, onde não abundam as representações figurativas deste período.

Apesar da deterioração que a peça apresenta, a sua observação atenta permite, com reservas, identificar algumas das figuras, nomeadamente através da presença de atributos

\footnotetext{
${ }^{5}$ FERNANDES, Carla Varela - "Fichas de catálogo"..., p. 316.
} 
iconográficos que tornam lícito afirmar que estamos perante representações de Santos e Santas da Cristandade. Para além dos atributos que é possível reconhecer, contribuem para a tentativa de identificação das figuras representadas a distinção de género estabelecida pelo canteiro através de certos detalhes fisionómicos, como a barba e os cabelos. Apenas com base nestas características, é possível concluir que o artista terá procurado representar um total de quatro Santos e quatro Santas, dispostos de forma harmónica e alternada, de modo a que cada Santo seja sempre ladeado por uma Santa, e vice-versa. A eleição das figuras a representar terá sido da responsabilidade dos encomendadores e baseada na religiosidade e devoções populares mais comuns na região, parecendo de salientar, nesse âmbito, o facto de as figuras representadas remeterem em exclusivo para o culto dos Mártires dos primeiros séculos da Cristandade, não sendo possível identificar nesta peça indícios de invocações marianas ou Santos associáveis aos Panteões das Ordens religiosas, cujo culto só se acaba por afirmar com maior vigor na Modernidade.

Assim, partindo unicamente da análise dos aspetos iconográficos, com elevado grau de probabilidade encontram-se representados nesta peça de cantaria o Apóstolo São Pedro, que segura numa mão a inconfundível Chave e na outra um Livro, e Santa Bárbara, a figura feminina (imberbe) que exibe na palma da mão o que parece ser uma Torre, invocações tradicionalmente associadas às questões climáticas em geral e, por isso, a todos os títulos relevantes para os habitantes do termo de Tavira, cuja economia se baseava na produção agrícola e na exportação de produtos por via marítima. Parece ainda admissível a presença de Santa Catarina, aqui representada como uma figura feminina munida de uma espada. Santa Catarina é muitas vezes é representada em associação com a acima mencionada Santa Bárbara e, para além disso, é adotada no dealbar do século XVI como padroeira de uma das freguesias rurais do termo de Tavira (Santa Catarina da Fonte do Bispo), o que não deixa de constituir um forte indício da importância desse culto no âmbito local ${ }^{6}$.

\footnotetext{
${ }^{6}$ A respeito das representações medievais de Santa Catarina em terras algarvias importa referir, como termo de comparação, uma antiga pedra de fecho quatrocentista, hoje exposta no Museu Municipal de Loulé, na qual a Virgem Mártir é representada segurando a espada e com uma coroa na cabeça.
} 


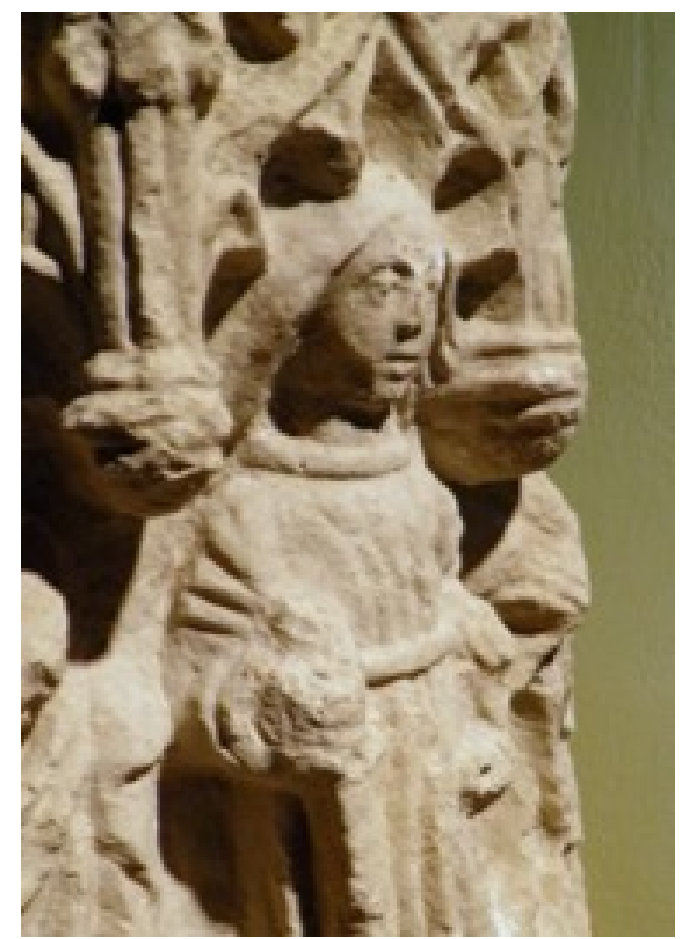

Fig. 2 - Pormenor do elemento de cantaria identificado com a referência MMT2285, do Museu Municipal de Tavira, com provável representação de Santa Catarina. Fonte: fotografia dos autores, 2014.

O desgaste da peça dificulta a tentativa de identificação das restantes figuras, admitindose, com as necessárias reservas, a presença de São Paulo, Apóstolo que sistematicamente surge associado a São Pedro, como um dos "Pilares da Igreja", e, eventualmente, de Santa Margarida, que muitas vezes figura junto das acima referidas Santa Bárbara e Santa Catarina, constituindo as três Virgens mártires do grupo de "Catorze Santos Auxiliares"", hipótese a respeito da qual não será descabido lembrar também que uma das ermidas existentes na periferia da cidade de Tavira tem como orago Santa Margarida.

De salientar ainda que uma das figuras masculinas não identificadas foi representada com a mão direita erguida remetendo para o gesto do orador, ou da Palavra, com um Livro na mão esquerda e barba bifurcada, recorrendo a um modelo iconográfico que se aproxima do geralmente utilizado nas representações de Cristo Pantocrator (Todo-Poderoso). Falta-lhe, porém, a auréola crucífera e, caso se tratasse da figura de Cristo, seria de esperar

\footnotetext{
${ }^{7}$ Trata-se de um conjunto de catorze Santos, sem ligação óbvia entre si e invocados por distintos motivos, que normalmente surgem associados por se acreditar que a sua virtude protetora se fortalece ao reuni-los. Este grupo de intercessores privilegiados inclui os Santos Acácio, Brás, Cristóvão, Ciríaco, Dionísio, Erasmo, Eustáquio, Egídio, Jorge, Pantaleão e Vito, e três Santas Bárbara, Catarina e Margarida. O seu culto teve início na Idade Média. Cf. DUCHET-SUCHAUX, Gaston; PASTOUREAU, Michel - La Biblia y los Santos. Guía Iconográfica. Madrid: Alianza Editorial, 1999, p. 83; TAVARES, Jorge Campos Dicionário de Santos, 3. a edição. Lisboa: Lello Editores, 2001.
} 
que a mesma tivesse um destaque mais evidente em relação às demais, nomeadamente em termos de escala. Apenas como hipótese de trabalho, não parece descabido que se possa tratar de uma representação de São Barnabé Apóstolo, Santo que foi escolhido como padroeiro de Tavira por alegadamente ter sido no dia da sua festa que os cavaleiros da Ordem de Santiago conquistaram a então vila. Os atributos não desmentem esta hipótese e, à partida, seria perfeitamente exequível encontrar uma representação do padroeiro da povoação numa peça de cariz apotropaico e elevado significado simbólico para a população local.

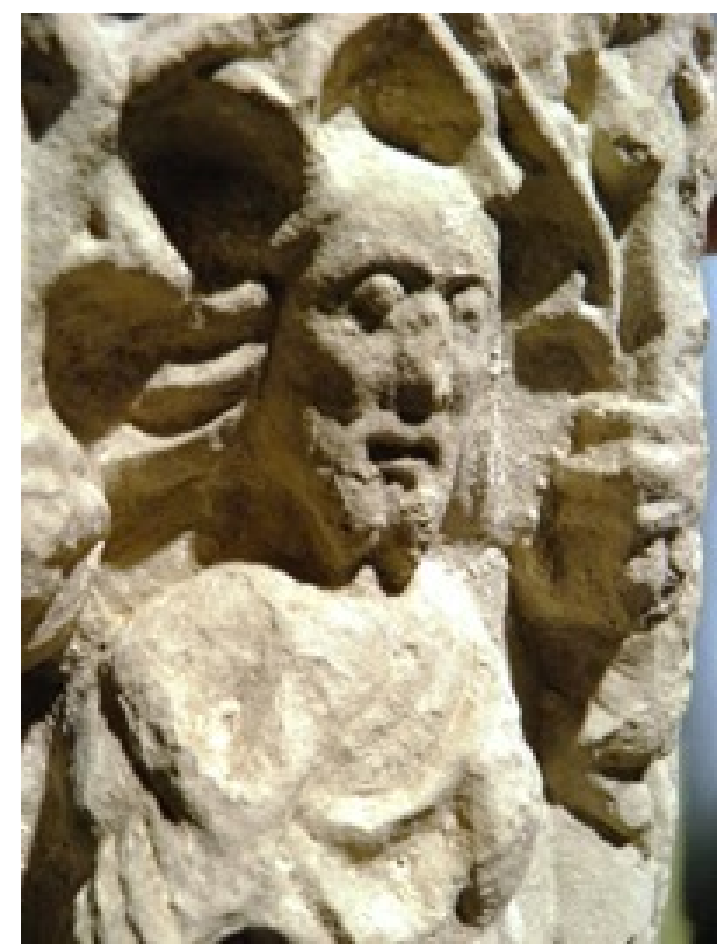

Fig. 3 - Pormenor do elemento de cantaria identificado com a referência MMT2285, do Museu Municipal de Tavira, com representação de Santo não identificado (São Barnabé?). Fonte: Fotografia dos autores, 2014.

Por último, e ainda em relação à identificação das figuras representadas, à partida é de estranhar a ausência nesta peça de uma representação de Santiago Maior, figura cara ao imaginário medieval português e patrono de uma das freguesias urbanas de Tavira, ou até de uma figura com atributos episcopais que possa configurar uma representação de São Brás, Santo não menos popular e a quem será consagrada uma das ermidas de fundação medieval do núcleo urbano. Em todo o caso, a questão da identificação de parte das invocações aqui representadas terá de permanecer em aberto, importando sobretudo 
reforçar o potencial desta peça para o conhecimento relativo à religiosidade popular de Tavira durante a Idade Média.

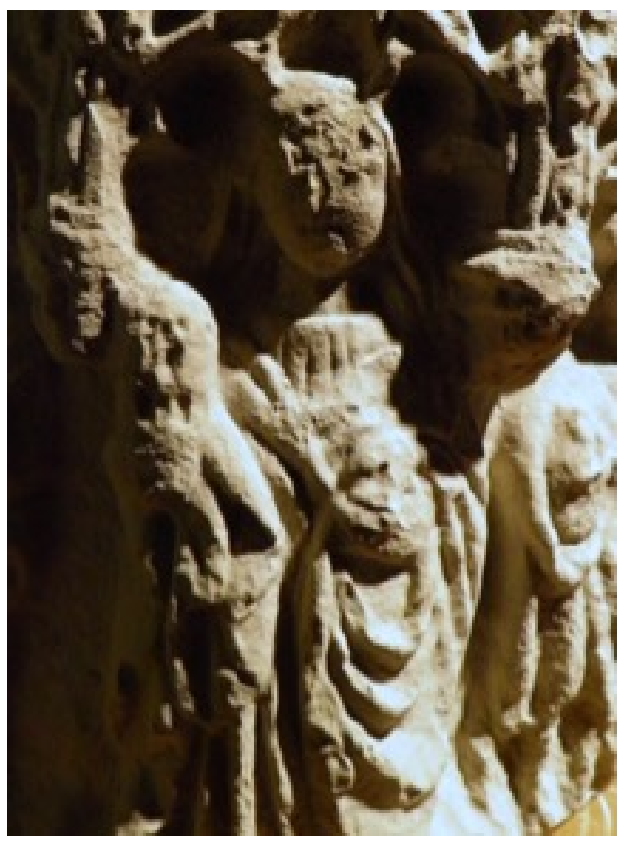

Fig. 4 - Pormenor do elemento de cantaria identificado com a referência MMT2285, do Museu Municipal de Tavira, com representação de Santa não identificado (Santa Bárbara?).

Fonte: fotografia dos autores, 2014

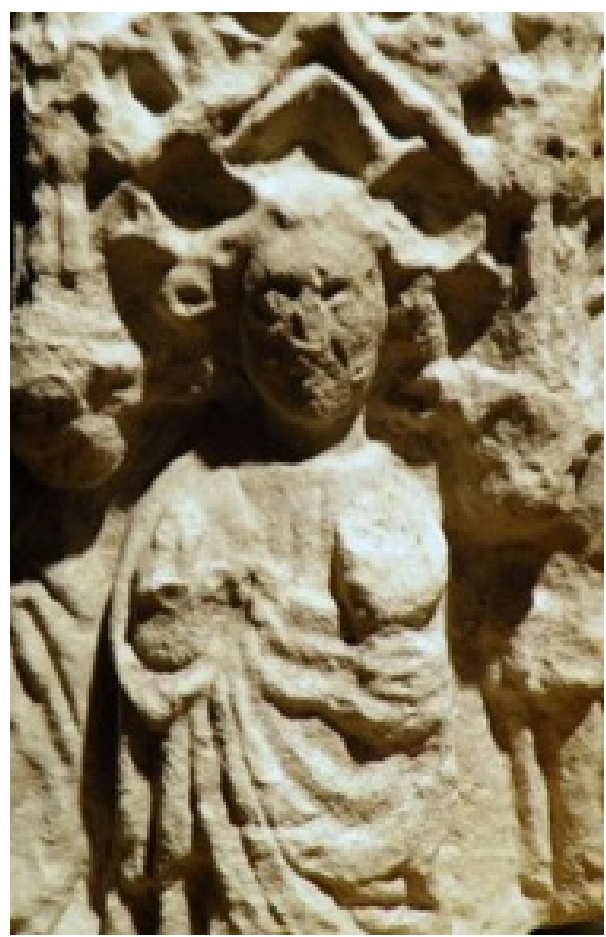

Fig. 5 - Pormenor do elemento de cantaria identificado com a referência MMT2285, do Museu Municipal de Tavira, com representação de Santo não identificado.

Fonte: fotografia dos autores, 2014. 


\section{Proposta de identificação da peça}

Tendo em conta as características físicas e dimensões da peça em análise, tudo indica tratar-se de um elemento arquitetónico, quanto a isso não parece haver dúvida. Mas em que tipo de estrutura ou equipamento terá originalmente estado integrado? Será um capitel ou o elemento de um desaparecido pelourinho, como já anteriormente proposto? Ou antes um fragmento de um antigo cruzeiro, hipótese até agora não devidamente equacionada? Exploremos cada uma dessas possibilidades recorrendo à análise crítica de todas as fontes disponíveis e também ao estabelecimento de paralelos formais com outras peças semelhantes.

\section{Capitel?}

À partida, e uma vez que a peça estava implantada no espaço outrora ocupado por um extinto convento, podia de facto tratar-se de um antigo capitel originalmente integrado nesse conjunto claustral (ou num dos outros que existiram na cidade), ainda que a hipótese não seja sustentada pela sua invulgar riqueza ornamental nem pelo facto de se tratar de uma peça de planta circular, tipologia pouco comum em claustros. Não obstante, a verdade é que, ainda em âmbito conventual, poderia ter estado integrada numa estrutura de carácter excecional, por exemplo numa Casa do Capítulo. Há exemplos de Casas do Capítulo cuja cobertura em abóbada é suportada por apenas uma coluna e, nesse caso, tratando-se de um espaço tão relevante e principal, talvez estivesse justificado o recurso a uma peça de carácter extraordinário e elevado valor artístico. Portanto, e pelo menos em teoria, não parece de descartar a hipótese de se tratar de um capitel. É verdade que os encaixes que apresenta no topo não parecem conciliáveis com a sua utilização enquanto capitel, mas, não obstante, o que é facto é que os mesmos podem ter sido executados em qualquer época, porventura na sequência de um reaproveitamento do elemento arquitetónico, não se podendo garantir que a sua abertura seja coeva da execução da peça. 


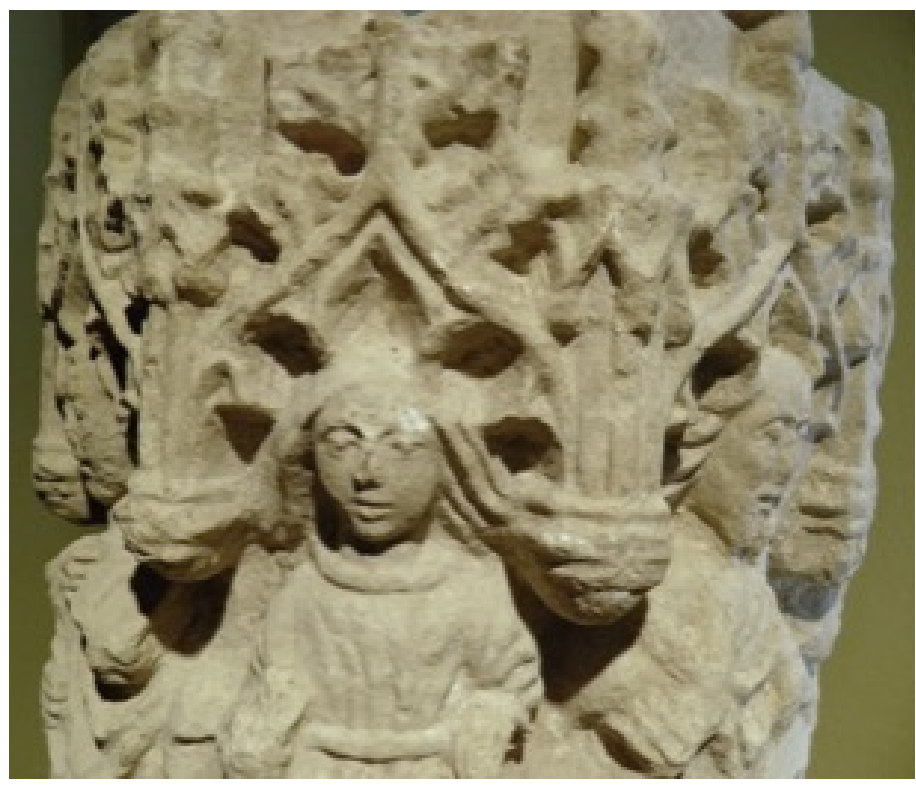

Fig. 6 - Pormenor de uma das faces do elemento de cantaria identificado com a referência MMT2285, do Museu Municipal de Tavira.

Fonte: fotografia dos autores, 2014.

\section{Elemento de pelourinho?}

Como qualquer povoação com autonomia administrativa, Tavira teve pelourinho, símbolo máximo do poder concelhio. Na verdade, ao que tudo indica, Tavira terá tido até dois pelourinhos diferentes, o primeiro provavelmente levantado logo após a conquista da povoação pelos cristãos, na década de 40 do século XIII ${ }^{8}$, ou aquando da outorga do primeiro foral à terra (1266), localizado dentro do perímetro amuralhado, junto à porta da antiga alcáçova e residência do alcaide-mor; e o segundo, talvez erguido no século XVIII, nas proximidades do edifício seiscentista dos Paços do Concelho, na zona da Ribeira, admitindo-se inclusive que as duas peças possam ter coexistido durante algum tempo ${ }^{9}$.

Do primitivo pelourinho de Tavira, e respetiva localização, somente se sabe que no final do século XVIII estava implantado no denominado Largo do Castelo, em frente à porta da antiga alcáçova medieval, como se comprova a partir da análise de uma planta cuja autoria é atribuída ao coronel José de Sande Vasconcelos, datável de cerca de 1800, na

\footnotetext{
${ }^{8}$ A mais antiga referência documental explícita à existência de um pelourinho em Tavira será uma carta manuscrita por Rui de Melo, em 1537, na qual se dava conta de que o Juiz de Tavira prendera Diogo Pessanha por ter morto dois membros da família Melo, sendo-lhe apresentada sentença pela qual se mandava que o preso fosse "levado ao pelourinho e lhe fosse cortada a cabeça", o que não se fez por este vir com embargos (ANTT, Coleção de cartas, Núcleo Antigo 877, n. ${ }^{\circ} 376$ ).

${ }^{9}$ Cf. VARGAS, José Manuel - "Os dois pelourinhos de Tavira". Jornal do Sotavento (5 de junho de 2009).
} 
qual se assinala a presença do "pelourinho velho". É provável que, nessa data, o pelourinho se encontrasse na sua localização original, já que era no castelo, ou melhor, na antiga alcáçova, que se situava o paço do alcaide-mor ${ }^{10}$, circunstância que se mantinha em meados do século XVIII ${ }^{11}$. Seja como for, tendo em conta que o pelourinho constituía um símbolo do poder concelhio, tampouco parece de descartar a hipótese de que, durante algum período, o pelourinho possa ter estado no topo da Rua Nova Grande, ou seja, nas proximidades da Casa da Câmara e Cadeia de fundação quinhentista, já fora do perímetro amuralhado.

Tanto quanto foi possível apurar, nada mais se sabe acerca do dito "pelourinho velho" de Tavira, seu aspeto, cronologia de execução ou locais de implantação. Mas, do ponto de vista formal e iconográfico, será que o elemento de cantaria hoje integrado nas coleções do museu municipal com a referência MMT2285 poderá ter feito parte do conjunto arquitetónico que constituía esse pelourinho antigo? Parece pouco provável, desde logo pelo tipo de iconografia que nele se observa, integrando nichos preenchidos com representações de Santos e Santas. Faltam-lhe os atributos próprios do poder secular que geralmente se encontram nos pelourinhos, nomeadamente coroas reais ou escudos com as armas reais, ou ainda com as do concelho. Contudo, a verdade é que essa condição, por si só, não será suficiente para excluir por completo a hipótese de se tratar de um capitel de pelourinho.

Uma vez expostos e analisados os dados que se conhecem em relação ao dito "pelourinho velho", vejamos o que se pode apurar a respeito do outro pelourinho que terá existido na cidade, e que, por uma questão de simplicidade, passaremos a designar como o "novo". Um dos mais antigos testemunhos da existência deste pelourinho "novo" será uma outra planta da cidade de Tavira datada do final do século XVIII, cuja autoria é atribuída ao já referido José de Sande Vasconcelos, na qual se representa, junto ao rio, no extremo da praça e nas proximidades do edifício ribeirinho dos Paços do Concelho, um elemento identificado como "peloirinho". Em 1825 esse elemento ainda se mantinha junto ao cais,

\footnotetext{
${ }^{10}$ Nesse sentido, de sublinhar que já em 1367 os alcaides-mores de Tavira eram obrigados, por força das funções que desempenhavam, a residir no castelo (Cf. ANICA, Arnaldo Casimiro - Tavira e o seu Termo. Tavira: Câmara Municipal de Tavira, 1993, p. 92).

${ }^{11}$ Em 1741, o então alcaide-mor, Manuel Inácio da Cunha Meneses e Távora, ainda residia no interior do castelo (ADF, Notariais de Tavira, cota 8-5-287, fólio 54).
} 
à beira do Gilão, como se verifica numa planta dessa data executada no âmbito do projeto de encanamento da barra da cidade.

O pelourinho "novo" terá permanecido junto ao edifício dos Paços do Concelho, na zona ribeirinha, até 1864 , data em que o executivo camarário toma a decisão de o demolir ${ }^{12}$, ficando registado na ata da sessão de câmara de 4 de junho de 1864 que a iniciativa se justificava "não só por ser um monumento de vergonhosa recordação como pela grosseiríssima forma da sua construção" ${ }^{13}$. Ou seja, a vereação justifica a demolição com questões ideológicas, conotando a peça com uma época de má memória, mas também por o considerar uma obra sem mérito artístico. A demolição do pelourinho teria lugar a 26 de junho de $1864^{14}$.

A classificação estética do pelourinho serviu de argumento para fundamentar a decisão política de o demolir. Porém, uma vez que não se conhece qualquer representação pormenorizada da peça, e na impossibilidade de avaliar os critérios estéticos da edilidade de 1864 , resta-nos a opinião declarada e a questão: será que o elemento de cantaria que constitui o objeto do presente artigo pode ter sido classificada, em 1864, como uma obra de "grosseiríssima forma"? Parece improvável, mas não impossível. Para melhor dissecar essa hipótese, vejamos o que se escreveu em relação às características formais do pelourinho "novo" de Tavira. Em 1935, num texto dado à estampa na imprensa local, adianta-se que o pelourinho da cidade, que até meados do século XIX se erguia na então Praça da Constituição, um pouco a jusante do edifício da Principal (Corpo da Guarda), constava de "uma base que assentava sobre três degraus quadrados, da qual saía um fuste cilíndrico rematado por um capitel que segurava uma bola ou pelouro, medindo tudo uns seis ou sete metros". O autor afirma igualmente que, nessa data (1935) existiam ainda testemunhas oculares que se recordavam de ver o pelourinho na praça. Porém, sublinhese, os testemunhos orais citados pelo autor afirmavam que, sem nunca abandonar a Praça da Constituição, o pelourinho também teria estado colocado junto à fachada dos edifícios fronteiros ao edifício dos Paços do Concelho, e não apenas junto ao rio, circunstância que se comprovaria através de uma imagem representada no pano da boca de cena do antigo

\footnotetext{
${ }^{12}$ Cf. ANICA, Arnaldo Casimiro - Tavira e o seu Termo ..., p. 92.

${ }^{13}$ AMT, Livro de Acórdãos da Câmara Municipal de Tavira (1863-1867), fólios 42v e 43.

${ }^{14}$ AMT, Livro de Receita e de Despesa da Câmara Municipal de Tavira (1848-1868), fólio 188.
} 
Teatro António Pinheiro ${ }^{15}$. A teoria de que o pelourinho era visível na supramencionada fotografia acabaria por ser difundida por outros autores que se debruçaram sobre o tema ${ }^{16}$. Todavia, através de uma fotografia da mesma praça tirada a partir de outro ângulo, e de um levantamento das fachadas que formavam essa frente de rua no final do século XIX, comprova-se que a silhueta identificada como sendo a de um pelourinho correspondia na verdade ao portal de cantaria de uma habitação civil, hoje desaparecido. A confusão era provocada pelo ângulo da fotografia já que, visto de esguelha, o perfil do referido portal era de facto semelhante ao de um pelourinho, mas sobretudo devido à pouca definição da fotografia. Seja como for, o que se conclui é que, ao contrário do que foi proposto por alguns autores, o pelourinho de Tavira não esteve colocado junto à fachada dos edifícios fronteiros ao edifício dos Paços do Concelho.

Em 1939, Damião de Brito Vasconcelos faz outra descrição formal do pelourinho que tinha existido em Tavira, que seria constituído por "uma tosca coluna de pedra que tinha no topo uma gaiola de ferro que girava horizontalmente e encimada por um espigão do mesmo metal". Adianta ainda o autor: nos "lados da coluna estavam chumbadas argolas de ferro e a coluna erguia-se sobre um estrado quadrado de granito, para o qual se subia quatro degraus de tijolo que o faceavam por todos os quatro lados" ${ }^{17}$. É curioso que, no ano de 1939, Damião de Vasconcelos refira o remate do pelourinho como sendo constituído por uma gaiola de metal, de certo modo contrariando a outra descrição datada de 1935, acima reproduzida, na qual se indica que o pelourinho era rematado por uma bola ou pelouro. A questão é particularmente relevante porquanto as descrições, para além de não serem coincidentes, remetem para tipologias de pelourinhos distintas, os de bola e os de gaiola $^{18}$, cuja denominação é atribuída tendo em conta o tipo de remate.

Em 1962, Luís Chaves informa que Tavira "teve pelourinho que era de forma cilíndrica, sobre uma base de 1,5 m quadrados, com degraus por quatro lados, situado junto do rio"19,

\footnotetext{
15 “O Pelourinho". O Povo Algarvio 55 (9 de junho de 1935).

16 "O Pelourinho de Tavira”. Correio do Sul 1056 (13 de junho de 1937).

17 VASCONCELOS, Damião Augusto de Brito - "O Pelourinho de Tavira”. O Povo Algarvio 248 (26 de fevereiro de 1939).

18 A respeito das diferentes tipologias de pelourinhos em Portugal, veja-se, por exemplo: LEITE, Ana Cristina - "Os centros simbólicos". in PEREIRA, Paulo (dir.) - História da Arte Portuguesa. Vol. II. Lisboa: Círculo de Leitores, 1995, pp. 86-90.

${ }^{19}$ CHAVES, Luís - "O pelourinho de Tavira”. Correio do Sul 2299 (29 de março de 1962).
} 
admitindo-se que esta descrição tenha sido produzida com base nas informações recolhidas no final do século XIX, ou já nos primeiros anos da centúria seguinte, pelo arqueólogo Silva Leal ${ }^{20}$. Curiosamente, o autor não vai avançar qualquer informação em relação ao tipo de remate desse elemento. Refere-se decerto ao pelourinho "novo", já que o "velho" nunca terá estado colocado junto ao rio.

Mas será que, após a demolição dos dois pelourinhos que alegadamente existiram em Tavira, foi preservado algum dos seus elementos? Tudo indica que não. De facto, pelo decreto n. ${ }^{\circ}$ 23.122, de 11 de outubro de 1933, o Governo determina a urgência de se proceder à classificação e inventariação "de todos os pelourinhos" ainda existentes no atual território nacional, inclusive aqueles já desmantelados, determinando-se ainda que, se possível, esses elementos fossem repostos na sua localização original. Na sequência da publicação desse decreto, a edilidade tavirense recebe, em dezembro de 1933, um pedido de esclarecimento. Não se sabe ao certo se houve alguma resposta por parte da Câmara ao pedido governamental, mas (não obstante as diligências efetuadas nesse sentido) não foi possível localizar qualquer informação enviada pelos serviços camarários, o que sugere que não haveria qualquer notícia a prestar acerca do tema. O que se pode atestar é que quando o relatório, produzido na sequência do inquérito, foi publicado, no ano de 1935, apenas constam referências à existência de fragmentos de quatro pelourinhos no distrito de Faro, todos deslocados do original local de implantação, a saber: em Castro Marim, Silves, Loulé e Monchique ${ }^{21}$.

Portanto, e perante os dados atualmente conhecidos, parece lícito concluir que a peça de cantaria lavrada hoje arrecadada nas coleções do Museu Municipal de Tavira, e identificada com a referência MMT2285, não será um dos elementos do antigo pelourinho da cidade, como chegou a ser proposto por alguns autores. De facto, o seu aspeto formal não coincide com qualquer das descrições do pelourinho conhecidas e, para além disso, há testemunhos que sugerem que o antigo pelourinho foi desmantelado e os seus elementos destruídos, ou extraviados, ainda durante a centúria de oitocentos. De algum modo robustecendo essa hipótese, refira-se que nos anos 30 do século XX nem os serviços

\footnotetext{
${ }^{20}$ Cf. VARGAS, José Manuel - "Os dois pelourinhos de Tavira"...

${ }^{21} \mathrm{Cf}$. Academia Nacional de Belas Artes, Pelourinhos - inventário conforme o inquérito determinado pelo decreto $n .^{\circ} 23.122$ de 11 de outubro de 1933. Lisboa: 1935.
} 
camarários, responsáveis pela obra de desmantelamento do pelourinho em 1864, teriam conhecimento da manutenção de qualquer dos antigos elementos do desaparecido símbolo do poder concelhio.

\section{Fragmento de um cruzeiro?}

Será que o elemento de cantaria identificado nas coleções do Museu Municipal de Tavira com a referência MMT2285 terá pertencido a um cruzeiro? Certo é o facto de alguns autores o terem identificado como tal, adiantando até que, enquanto parte de um cruzeiro, ele teria estado colocado no adro da igreja do convento de São Francisco ou no adro da desaparecida ermida do Espinheiro $^{22}$, que existiu na zona da Atalaia, em Tavira. A hipótese parece especialmente plausível na medida em que a maior parte das ermidas, igrejas paroquiais e casas religiosas dispunham (e algumas dispõem ainda) de cruzeiros associados.

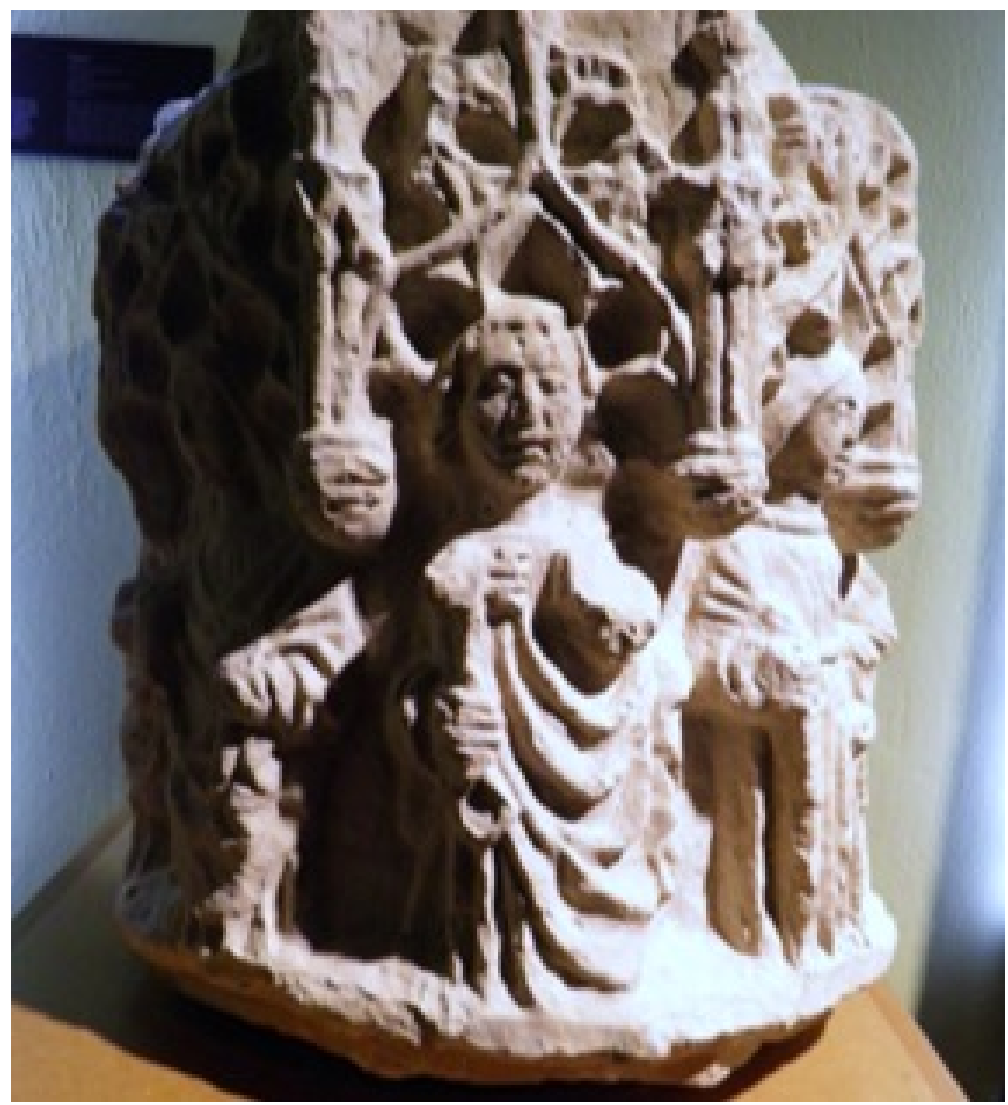

Fig. 7 - Pormenor de uma das faces do elemento de cantaria identificado com a referência MMT2285, do Museu Municipal de Tavira.

Fonte: fotografia dos autores, 2014.

${ }^{22}$ FRANCO, Armando da Costa - "Subsídios para o Museu de Tavira”... 
Desde logo não será de estranhar a admissível existência de um cruzeiro no adro de São Francisco, em Tavira, circunstância que à partida justificaria o facto de a peça ter sido depois transferida e instalada no vizinho cemitério, no preciso local onde se haviam erguido a igreja e as instalações conventuais dos franciscanos. Há numerosos exemplos de antigos conventos franciscanos com cruzeiros associados ${ }^{23}$, incluindo no Algarve. Em Faro, por exemplo, em frente à igreja da Ordem Terceira de São Francisco pode ainda observar-se o cruzeiro que originalmente assinalava o limite da propriedade dos frades franciscanos que residiam no vizinho convento. Ainda no que respeita à possibilidade de a peça em estudo ter estado integrada num cruzeiro outrora implantado no adro de São Francisco, não será descabido lembrar que esse mesmo terreiro era partilhado pelo Hospital do Espírito Santo, instituição fundada no último quartel do século XV, e que os hospitais eram igualmente construções passíveis de ter associadas a si cruzeiros, como se verifica, por exemplo, no caso do antigo Hospital de Nossa Senhora dos Pobres de Loulé, obra de fundação quinhentista.

Por outro lado, tampouco seria de estranhar a existência de um cruzeiro junto à referida ermida de Nossa Senhora do Espinheiro, no subúrbio da Atalaia, a respeito da qual apenas se sabe que já existia no final do século XVI, e que se encontrava "posta em um rossio", sendo denominada como de Nossa Senhora "da Esperança, do Espinheiro, ou da Atalaia", templo que é posteriormente entregue pela Câmara aos Capuchos da Piedade para nele fundarem uma nova Casa religiosa ${ }^{24}$.

Contudo, para além das referências acima indicadas, quase sempre sustentadas na tradição oral, há alguma referência documental à existência de um cruzeiro em Tavira? Tanto quanto foi possível apurar, não se conhecem referências à existência de qualquer cruzeiro mas, não obstante, sabe-se que eles existiam em praticamente todas as povoações da região e, para além disso, numa planta da cidade de Tavira executada no século XVII,

\footnotetext{
${ }^{23}$ Em vários pontos do território nacional podem observar-se cruzeiros associados a igrejas de antigos conventos franciscanos, podendo referir-se, apenas a título de exemplo, os casos de Viana do Castelo, Guimarães ou Estremoz.

${ }^{24}$ A primeira pedra do novo convento, que ficaria com a invocação de Santo António da Esperança, por referência à antiga ermida que naquele local se erguia, foi colocada a 16 de dezembro de 1612 (MONFORTE, Frei Manuel de - Crónica da Província da Piedade. Lisboa: Oficina de Miguel Manescal da Costa, 1751, pp. 641-643).
} 
alegadamente a partir de um original quinhentista (integrada no Atlas do Marquês de Heliche $^{25}$ ), é representado um cruzeiro situado no extremo do perímetro urbano, mais precisamente junto à bifurcação das estradas que seguiam para a cidade de Faro e para o lugar da Fonte do Bispo (Santa Catarina da Fonte do Bispo). É verdade que na planta foi representado um cruzeiro sem qualquer semelhança com a peça exposta no museu municipal, mas parece exequível que, na impossibilidade de representar detalhes, o autor tenha optado por apresentar uma versão mais estilizada do mesmo, ou seja, uma simples cruz.

Admitindo que estamos perante um elemento proveniente de um antigo cruzeiro, parece mais provável que uma peça com a riqueza iconográfica e delicadeza de corte da MMT2285 estivesse colocada em pleno núcleo urbano, numa área privilegiada do ponto de vista urbanístico, e não numa bifurcação de estrada totalmente periférica. Contudo, em teoria, nada impede a colocação de uma peça com este grau de requinte artístico num local isolado, como comprovam casos como o do cruzeiro tardogótico (ou já manuelino) que originalmente se terá erguido no ilhéu de Nossa Senhora do Rosário, em pleno Rio Arade (Vila Nova de Portimão), ou o da célebre Cruz de Portugal, em Silves, que ainda na primeira metade do século XIX o cronista João Baptista da Silva Lopes afirmava estar situada "a uns seiscentos passos da cidade"26, apenas para citar dois exemplos geograficamente próximos do objeto de estudo deste texto. Assim, partindo do princípio de que a MMT2285 pertenceu a um cruzeiro, não repugna a ideia de que possa ter estado colocada na periferia da então vila, junto à bifurcação da estrada que seguia de Tavira para Faro, no preciso local onde a planta da cidade de Tavira integrada no Atlas do Marquês de Heliche testemunha ter existido um cruzeiro.

Não há dúvida, portanto, de que existiu em Tavira um cruzeiro, ou porventura até mais, já que a tradição oral guarda a memória da existência de um desses elementos no adro de São Francisco, outro no adro da ermida do Espinheiro, na Atalaia, e há até um registo cartográfico que assinala a existência de outro cruzeiro na periferia da cidade. Em teoria,

\footnotetext{
${ }^{25}$ A respeito do denominado Atlas del Marquês de Heliche, no qual se encontra esta planta da cidade de Tavira, veja-se: RUBIO, Rocío Sánchez; NÚÑEZ, Isabel Testón; RUBIO, Carlos M. Sanchéz - Imágenes de un Imperio Perdido - el Atlas del Marques de Heliche. Badajoz: Editora 4 Gatos, 2004.

${ }^{26}$ LOPES, João Baptista da Silva - Memórias para a história eclesiástica do bispado do Algarve. Lisboa: Academia Real das Ciências, 1848, p. 125.
} 
em qualquer um desses espaços pode ter estado colocado um cruzeiro ou, em última análise, o mesmo cruzeiro poderá ter estado implantado, em épocas distintas, em diferentes locais. De facto, este tipo de cruzes correspondia a uma vontade de estabelecer marcos referenciais, a fim de ordenar e hierarquizar a paisagem, os caminhos, as ruas, as praças ou os montes, sacralizando o espaço ocupado, pelo que não era invulgar encontrálas à entrada ou saída das povoações, junto a caminhos ou servindo de indicação dos mesmos, assinalando um local de prece para quem partia, que esperava alcançar a bênção de Deus ou dos Santos para a viagem que iria empreender, mas também para o viajante que chegava e o via como um sinal de boas-vindas, uma bênção divina que indicava a proximidade do destino. De resto, não será por acaso que uma das figuras representadas nas faces da MMT2285 é Santa Bárbara, a qual se invocava contra as intempéries, mas também contra os perigos da morte súbita, um dos maiores temores do cristão que viajava e receava falecer sem receber os devidos Sacramentos.

Ganha força, portanto, a teoria de que a MMT2285 possa afinal ser um elemento de um desaparecido cruzeiro. Mas será que existem, a nível nacional, outros exemplares que, do ponto de vista formal, sustentem essa hipótese? Isto é, analisando as características formais da peça em estudo, podem estabelecer-se paralelos com cruzeiros semelhantes que existam (ou tenham existido) em território nacional? A verdade é que sim. Numa gravura dada à estampa em 1847, na revista Portugal Pitoresco, acompanhada por uma legenda explicativa que a identifica como o antigo pelourinho da vila de Porto de Mós ${ }^{27}$ (já desaparecido), foi representado um capitel de cruzeiro com planta facetada e preenchida com figuras de Santos dentro de nichos. Não obstante a legenda que identifica a gravura, não se trata decerto de um pelourinho, mas de um cruzeiro, circunstância que se depreende do facto de o mesmo apresentar os ditos nichos com Santos e ser encimado por uma cruz, mas também porque na gravura se observa, junto à base da estrutura, o que parece ser a figura de um sacerdote e figuras femininas ajoelhadas, em aparente atitude de oração. Ou seja, não é seguramente um símbolo do poder secular. Do ponto de vista formal, as analogias com a MMT2285 são por demais evidentes. Outro elemento com óbvias semelhanças formais e compositivas com a peça MMT2285 é o capitel do cruzeiro existente junto à matriz do Cartaxo, peça de cronologia quinhentista, cujo remate

\footnotetext{
${ }^{27}$ DENIS, M. Fernando - Portugal Pitoresco, Vol. IV. Lisboa: Tipografia de L.C. da Cunha 1847, p. 219.
} 
apresenta planta circular e as faces preenchidas por nichos com representações de Santos e Santas, sendo encimado por uma cruz. Portanto, há de facto paralelos formais que parecem sustentar a hipótese de que a peça de Tavira possa ser um antigo capitel de cruzeiro.

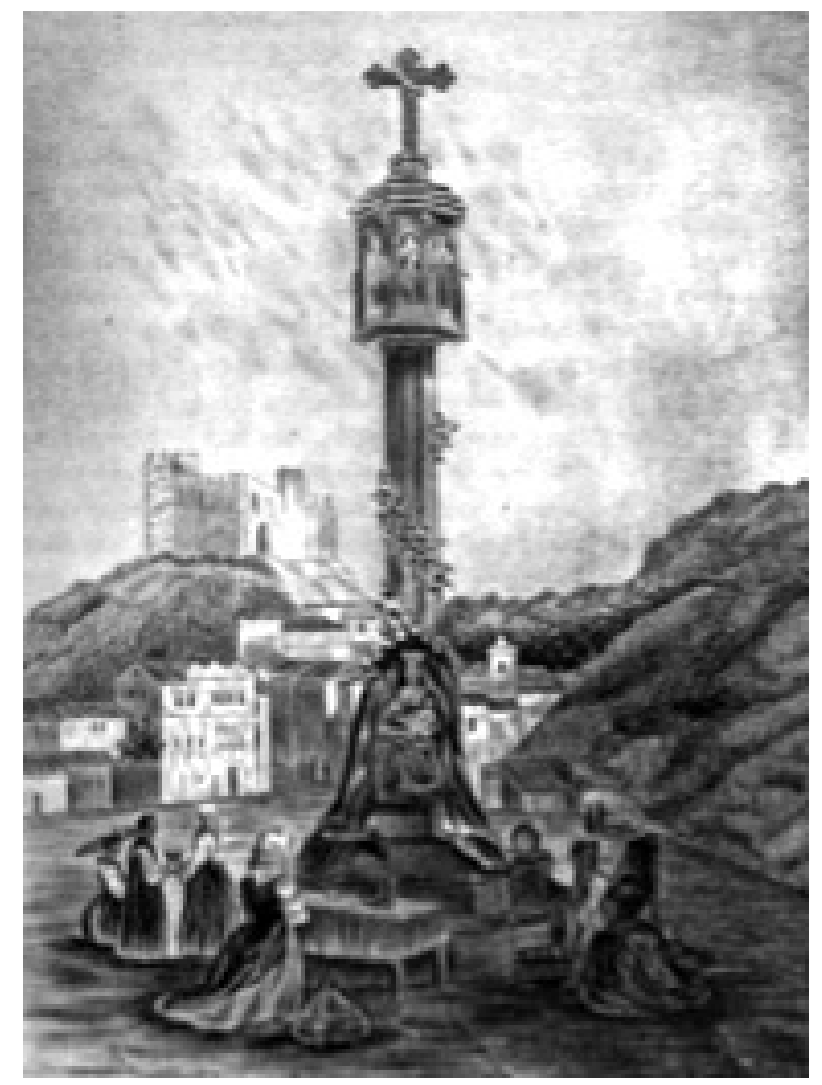

Fig. 8 - Gravura do antigo cruzeiro de Porto de Mós.

Fonte: DENIS, M. Fernando - Portugal Pitoresco. Vol. IV. Lisboa: Tipografia de L.C. da Cunha, 1847, p. 219. 


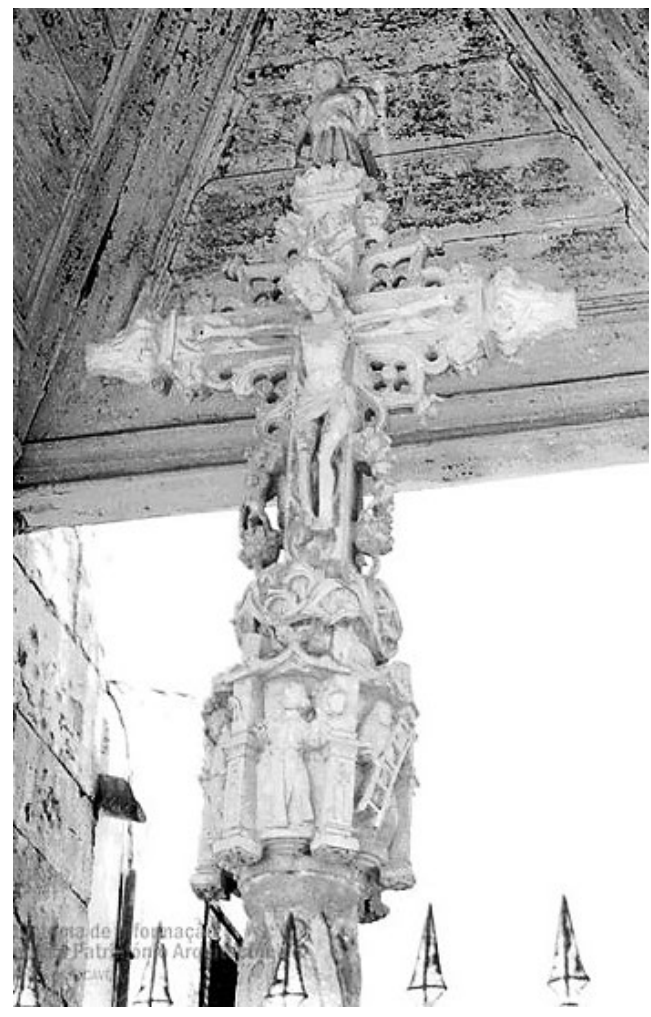

Fig. 9 - Pormenor do remate do cruzeiro do Cartaxo.

Fonte: Sistema de Informação para o Património Arquitetónico, SIPA.FOTO 00506036, extraído do site: http://www.monumentos.gov.pt/Site/APP PagesUser/Default.aspx.

Já aqui foram assinaladas as analogias formais entre a peça MMT2285 e capitéis de outros cruzeiros constituídos por coluna ou pilarete de seção circular, quadrada, hexagonal ou octogonal colocada sobre um plinto ou base, circular ou quadrada, com um ou vários degraus, capitel decorado com figuras e arcos e rematados por cruz, geralmente com Cristo no anverso e com Nossa Senhora da Piedade no reverso. Contudo, no caso de Tavira perderam-se os elementos que completavam a peça MMT2285, talvez sacrificados pelas transformações da malha urbana ou no âmbito dos destrutivos processos de requalificação de estradas encetados a partir do século XIX. Em todo o caso, talvez valha a pena lembrar que a peça guardada em Tavira apresenta no topo uma profunda cavidade com formato cúbico, no qual podia ter estado encaixada a base de uma cruz, e alguns orifícios mais pequenos dispostos aos pares em torno dos ângulos destas concavidades e que, a título de hipótese, podiam ter servido para encaixar outros elementos de menor dimensão, porventura peças metálicas utilizadas para pendurar candeias que iluminassem o cruzeiro na escuridão. 


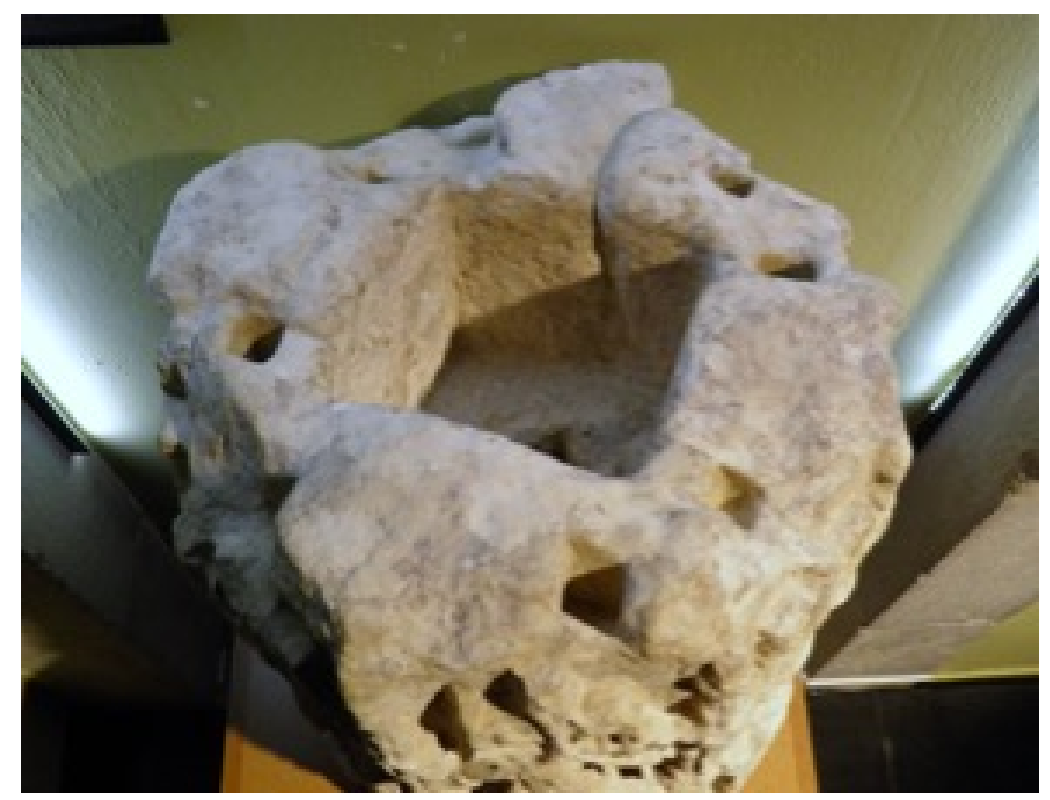

Fig. 10 - Pormenor da face superior do elemento de cantaria identificado com a referência MMT2285, do Museu Municipal de Tavira, com orifícios escavados. De forma regular. Fonte: fotografia dos autores, 2014.

\section{Notas finais}

Em resumo, o que se pode concluir de tudo o que fica exposto é a que a hipótese que se apresenta como mais plausível é a de que a peça de cantaria até agora identificada como a MMT2285, um invulgar elemento pétreo de planta circular esculpido com oito figuras de Santos e Santos inscritas dentro de arcos, seja afinal um elemento de um cruzeiro quatrocentista originalmente implantado num dos espaços públicos de Tavira. Pelo seu elevado valor artístico e cultural, esta peça, até à data pouco valorizada e hoje recolhida e conservada no Museu Municipal de Tavira, assume-se como fundamental para o estudo e valorização das manifestações de pequena arquitetura devocional que pontuavam a região de Tavira e o Algarve em geral. 


\section{REFERÊNCIAS BIBLIOGRÁFICAS}

\section{Fontes}

\section{Fontes manuscritas}

Lisboa, Arquivo Nacional da Torre do Tombo (ANTT), Coleção de cartas, Núcleo Antigo 877, n. ${ }^{\circ} 376$.

Faro, Arquivo Distrital de Faro (ADF), Notariais de Tavira, cota 8-5-287.

Tavira, Arquivo Histórico Municipal de Tavira, Livro de Acórdãos da Câmara Municipal de Tavira (1863-1867).

Tavira, Arquivo Histórico Municipal de Tavira (AHMT), Livro de Receita e de Despesa da Câmara Municipal de Tavira (1848-1868).

\section{Fontes impressas}

AAVV, Academia Nacional de Belas Artes - Pelourinhos - inventário conforme o inquérito determinado pelo decreto n. ${ }^{\circ} 23.122$ de 11 de outubro de 1933. Lisboa: 1935.

ANICA, Arnaldo Casimiro - Tavira e o seu Termo. Tavira: Câmara Municipal de Tavira, 1993.

ANICA, Arnaldo Casimiro - Tavira e o seu Termo - Memorando Histórico. Vol. II. Tavira: Câmara Municipal de Tavira, 2001.

DENIS, M. Fernando - Portugal Pitoresco. Vol. IV. Lisboa: Tipografia de L.C. da Cunha, 1847.

DUCHET-SUCHAUX, Gaston; PASTOUREAU, Michel - La Biblia y los Santos. Guía Iconográfica. Madrid: Alianza Editorial, 1999. 
FERNANDES, Carla Varela - "Fichas de catálogo". in Tavira - território e poder (catálogo de exposição). Tavira: Câmara Municipal de Tavira / Museu Municipal (Palácio da Galeria), 2006.

LEITE, Ana Cristina - “Os centros simbólicos”. in PEREIRA, Paulo (dir.) - História da Arte Portuguesa. Vol. II. Lisboa: Círculo de Leitores, 1995.

LOPES, João Baptista da Silva - Corografia ou Memoria Económica, Estadística e Topográfica do Reino do Algarve. Lisboa: Academia Real das Ciências, 1841.

LOPES, João Baptista da Silva - Memórias para a história eclesiástica do bispado do Algarve. Lisboa: Academia Real das Ciências, 1848.

MONFORTE, Frei Manuel de - Crónica da Província da Piedade. Lisboa: Oficina de Miguel Manescal da Costa, 1751.

RUBIO, Rocío Sánchez; NÚÑEZ, Isabel Testón; RUBIO, Carlos M. Sanchéz - Imágenes de un Imperio Perdido - el Atlas del Marques de Heliche. Badajoz: Editora 4 Gatos, 2004.

TAVARES, Jorge Campos - Dicionário de Santos, 3. a edição. Lisboa: Lello Editores, 2001.

VASCONCELOS, Damião Augusto de Brito - Notícias históricas de Tavira (12421840), $2^{\mathrm{a}}$ edição (com anotações de Arnaldo Casimiro Anica). Tavira: Câmara Municipal de Tavira, 1999.

\section{Estudos}

CHAVES, Luís - "O pelourinho de Tavira”. Correio do Sul 2299 (29 de março de 1962).

FRANCO, Armando da Costa - "Subsídios para o Museu de Tavira". Jornal do Sotavento (3 de maio de 1996). 
“O Pelourinho". O Povo Algarvio 55 (9 de junho de 1935).

“O Pelourinho de Tavira”. Correio do Sul 1056 (13 de junho de 1937).

VARGAS, José Manuel - "Os dois pelourinhos de Tavira”. Jornal do Sotavento (5 de junho de 2009).

VASCONCELOS, Damião Augusto de Brito - "O Pelourinho de Tavira". O Povo Algarvio 248 (26 de fevereiro de 1939).

\section{COMO CITAR ESTE ARTIGO}

\section{Referência electrónica:}

SANTANA, Daniel; SANTOS, Marco Sousa - "O cruzeiro medieval de Tavira". Medievalista 27 (Janeiro - Junho 2020). [Em linha] [Consultado dd.mm.aaaa]. Disponível em http://www2.fcsh.unl.pt/iem/medievalista/MEDIEVALISTA27/santanasantos2702.html

ISSN 1646-740X.

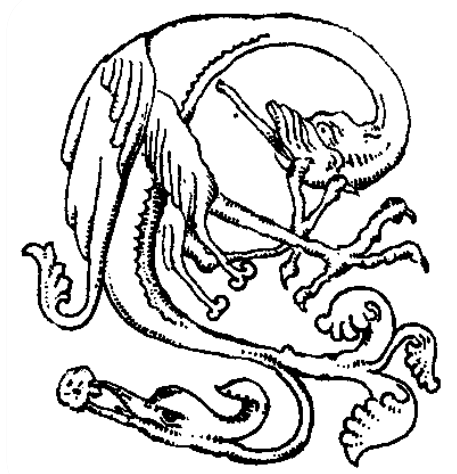

